\title{
PERAN GURU PKN UNTUK MEMBENTUK KARAKTER SISWA DENGAN MODEL PEMBELAJARAN ROLE PLAYING KELAS XI DI MADRASAH ALIYAH SABILAL AKHYAR KWALA BEGUMIT
}

\author{
${ }^{1}$ Nella Etika Lubis, ${ }^{2}$ Drs. H. Muslim Sembiring, MH \\ ${ }^{1}$ Mahasiswa STKIP Budidaya Binjai, ${ }^{2}$ Dosen STKIP Budidaya Binjai \\ Inellaetikalubis@gmail.com
}

\begin{abstract}
ABSTRAK
Tujuan penelitian ini adalah untuk mengetahui pengaruh peran guru PKn dalam membentuk karakter siswa kelas XI Madrasah Aliyah Sabilal Akhyar dengan menggunakan model Role Playing. Jenis penelitian ini merupakan penelitian eksperimen semu dengan desain non equivalent control group design. Sampel dalam penelitian ini adalah siswa kelas XI-A dengan jumlah siswa 32 siswa sebagai kelas kontrol dan siswa kelas XI-B dengan jumlah 30 siswa sebagai kelas eksperimen. Instrumen penelitian ini adalah menggunakan tes (pretets dan posttest). Berdasarkan hasil penelitian dan analisis data diperoleh $\mathrm{t}_{\text {hitung }}$ sebesar 4,5 sedangkan $t_{\text {tabel }}$ sebesar 2,05. Nilai ini menunjukkan bahwa $t_{\text {hitung }}>t_{\text {tabel }}(4,5>2,05)$ sehingga dapat disimpulkan bahwa terdapat pengaruh peran guru PKn membentuk karakter siswa Kelas XI Madrasah Aliyah Sabilal Akhyar dengan menggunakan model pembelajaran role playing.
\end{abstract}

Kata Kunci : Peran, Karakter, Role Playing.

\section{ABSTRACT}

The purpose of this study was to see the influence of the influence of Civics teachers in shaping the character of Class XI students of Madrasah Aliyah Sabilal Akhyar using the Role Playing model. This type of research is a quasi-experimental research with a non equivalent control group design. The samples taken in this study were students of class XI-A with 32 students as the control class and students of class XI-B with a total of 30 students as the experimental class. The research instrument was a test (pretets and posttest). Based on the results of research and data analysis, it was obtained tcount of 4.5 while ttable of 2.05. This value shows that tcount $>$ ttable (4.5> 2.05) so it can be ignored that there is an influence of the role of Civics teachers in shaping the character of Class XI students of Madrasah Aliyah Sabilal Akhyar using the role playing learning model.

Keywords: Role, Character, Role Playing.

\section{PENDAHULUAN}

Guru memiliki peran yang sangat unik dan kompleks di dalam proses pembelajaran untuk mengantarkan siswa ke taraf yang dicitacitakan sesuai dengan profesi dan tanggung jawabnya (Usman, 2002:17). Peran Guru PKn bukan hanya mengajar tetapi juga mendidik siswa agar menjadi manusia yang lebih baik dalam beretika dan bermoral, sehingga dapat mendisiplinkan siswa agar menjadi patuh terhadap aturan-aturan sekolah dan normanorma hidup dalam keluarga, masyarakat, bangsa dan negara (Anggraini dan Wibawa, 2019:151)

Peran guru sebagai tugas pendidikan meliputi mendidik, mengajar, dan melatih. Peran guru dalam menjalankan tugas di sekolah harus dapat menjadikan dirinya sebagai orang tua ke dua dan mampu menarik simpati para siswa sehingga pelajaran apapun yang diberikan hendaknya dapat menjadi motifasi bagi siswanya dalam mengajar.

Peran guru Pendidikan Kewarganegaraan (PKn) bukan hanya mentransfer pengetahuan kepada siswa, tetapi juga mentransfer nilai-nilai 
yang diharapkan dapat dipahami, disadari, dan diwujudkan dalam perilaku baik siswa. Menurut Usman (2002:56). peran guru dalam pembentukan karakter lebih difokuskan pada tiga peran, yaitu:

a. Peran pendidik sebagai pembimbing

Peran pendidik sebagai pembimbing sangat berkaitan erat dengan praktik keseharian. Untuk dapat menjadi seorang pembimbing, seorang pendidik harus mampu memperlakukan para siswa dengan menghormati dan menyayanginya. Ada beberapa hal yang tidak boleh dilakukan oleh seorang pendidik, yaitu meremehkan atau merendahkan siswa, memperlakukan sebagai siswa secara tidak adil, dan membenci sebagian siswa. Perlakuan pendidik sebenarnya sama dengan perlakuan orang tua terhadap anakanaknya yaitu penuh respek, kasih sayang serta memberikan perlindungan. Sehingga, siswa merasa senang dan familiar untuk sama-sama menerima pelajaran dari pendidiknya tanpa ada paksaan, tekanan dan sejenisnya. Pada intinya, setiap siswa dapat merasa percaya diri bahwa di sekolah, ia akan sukses belajar lantaran ia merasa dibimbing, didorong, dan diarahkan oleh pendidiknya. Bahkan, dalam hal-hal tertentu pendidik harus membimbing dan mengarahkan satu persatu dari seluruh siswa yang ada.

b. Peran pendidik sebagai model (model)

Peranan pendidik sebagai model pembelajaran sangat penting dalam rangka membentuk akhlak mulia bagi siswa yang diajar. Tindak tanduk, perilaku, dan bahkan gaya guru selalu diteropong dan dijadikan cermin (contoh) oleh siswa-muridnya. Kedisiplinan, kejujuran, keadilan, kebersihan, kesopanan, ketulusan, ketekunan, kehati-hatian akan selalu direkam oleh siswa-muridnya dan dalam batas-batas tertentu akan diikuti oleh siswa-muridnya. Demikain pula sebaliknya, kejelekan-kejelekan gurunya akan pula direkam oleh muridnya dan biasanya akan lebih mudah dan cepat diikuti oleh siswa-muridnya. Semuanya akan menjadi contoh bagi siswa, karenanya guru harus bisa menjadi contoh yang baik bagi siswa-muridnya. Guru juga menjadi figur secara tidak langsung dalam pembentukan akhlak siswa dengan memberikan bimbingan tentang cara berpenampilan, bergaul dan berprilaku yang sopan.

c. Peran pendidik sebagai penasehat

Seorang pendidik memiliki jalinan ikatan batin atau emosional dengan para siswa yang diajarnya. Dalam hubungan ini pendidik berperan aktif sebagai penasehat. Peran pendidik bukan hanya sekedar menyampaikan pelajaran di kelas lalu menyerahkan sepenuhnya kepada siswa dalam memahami materi pelajaran yang disampaikannya tersebut. Namun, lebih dari itu, guru juga harus mampu memberi nasehat bagi siswa yang membutuhkannya, baik diminta ataupun tidak.

Oleh karena itu hubungan batin dan emosional antara siswa dan pendidik dapat terjalin efektif, bila sasaran utamanya adalah menyampaikan nilai-nilai moral, maka peranan pedidik dalam menyampaikan nasehat menjadi sesuatu yang pokok, sehingga siswa akan merasa diayomi, dilindungi, dibina, dibimbing, didampingi oleh gurunya.

Pendidikan karakter bertujuan untuk meningkatkan mutu penyelenggaraan hasil pendidikan di sekolah yang mengarah pada pencapaian pembentukan karakter dan akhlak mulia siswa secara utuh, terpadu dan seimbang, sesuai dengan standar kompetensi lulusan. Melalui pendidikan karakter diharapkan siswa mampu secara mandiri meningkatkan dan menggunakan pengetahuan nilai-nilai karakter dalam perilaku sehari-hari (Sudrajat, 2010: 23). Untuk membentuk karakter pada siswa yaitu dengan menerapkan model pembelajaran Role Playing (bermain peran). Bermain peran adalah suatu model pembelajaran yang bertujuan 
untuk membantu siswa menemukan makna diri (jati diri) di dalam lingkungan sosial dan memecahkan masalah dengan bantuan kelompok.

Pendidikan karakter adalah sebuah sistem yang menanamkan nilai-nilai karakter pada siswa, yang mengandung komponen pengetahuan, kesadaran individu, tekad, serta adanya kemauan dan tindakan. Untuk melaksanakan nilai-nilai, baik terhadap Tuhan Yang Maha Esa, diri sendiri, sesama manusia, lingkungan, maupun bangsa, sehingga akan terwujud insan kamil. (Aunillah, 2011:18).

Pendidikan karakter terhadap anak hendaknya menjadikan mereka terbiasa untuk berperilaku baik, sehingga ketika anak tidak melakukan kebiasaan baik itu, yang bersangkutan akan merasa bersalah. Dengan demikian, kebiasaan baik sudah menjadi semacam instink, yang secara otomatis akan membuat seorang anak menjadi tidak nyaman bila tidak melakukan kebiasaan baik itu (Sukaimi, 2013: 86). Pendidikan karakter merupakan salah satu tujuan pendidikan nasional. Pasal I Undang-Undang Republik Indonesia Nomor 20 Tahun 2003 Tentang Sistem Pendidikan Nasional menyatakan bahwa "tujuan pendidikan nasional adalah mengembangkan potensi siswa untuk memiliki kecerdasan, kepribadian dan akhlak mulia". Amanah Undang-Undang Republik Indonesia Nomor 20 Tahun 2003 Tentang Sistem Pendidikan Nasional tersebut tidak hanya membentuk insan Indonesia yang cerdas tapi juga berkepribadian atau berkarakter, generasi berkarakter yang menghormati nilai-nilai luhur bangsa dan agama. Pondasi kebangsaan yang kokoh diharapkan dapat dibangun dengan bangkitnya kesadaran bangsa melalui pendidikan karakter.

Bagi orang tua, sekolah diharapkan menjadi salah satu tempat atau lingkungan yang dapat membentuk anak mengembangkan karakter yang baik sehingga apa yang didapatkannya di sekolah mempengaruhi pembentukan karakternya. Pendidikan karakter terhadap anak hendaknya menjadikan mereka terbiasa untuk berperilaku baik, sehingga ketika anak tidak melakukan kebiasaan baik itu, yang bersangkutan akan merasa bersalah. Dengan demikian, kebiasaan baik sudah menjadi semacam instink, yang secara otomatis akan membuat seorang anak menjadi tidak nyaman bila tidak melakukan kebiasaan baik itu (Sukaimi, 2013:86).

Megawangi (2004:31) mengungkapkan pentingnya pendidikan karakter di sekolah yakni "karena dengan adanya pendidikan karakter di sekolah dapat menurunkan perilaku saling mengejek sekolah dan juga menurunkan terjadinya perkelahian antar pelajar, sehingga suasana belajar akan semakin nyaman, dan akhirnya dapat meningkatkan prestasi akademik siswa".

Dengan kata lain pendidikan karakter di sekolah sangat penting karena akan menghindarkan atau mengurangi kelakuan-kelakuan buruk dari siswa seperti tidak lagi saling menjelek-jelekkan sekolah lain dan memamerkan sekolah sendiri, terhindarnya dari tawuran antar pelajar serta akan menghasilkan suasana belajar yang nyaman dan dapat meningkatkan prestasi akademik siswa serta mampu mengharumkan nama baik diri sendiri, keluarga, sekolah, masyarakat, bangsa dan negara.

Untuk membentuk karakter siswa dapat dilakukan dengan menerapkan model pembelajaran terntentu, seperti Role Playing (bermain peran). Menurut Hamzah (2007:26) bermain peran adalah salah satu bentuk permainan pendidikan (educational games) yang dipakai untuk menjelaskan perasaan, sudut pandang, dan cara berfikir orang lain (membayangkan diri sendiri seperti keadaan orang lain). Menurut Mulyadi (2011:136) langkah-langkah penerapan model Role Playing antara lain: 
a. Guru menyiapkan skenario yang akan ditampilkan.

b. Menunjuk beberapa siswa untuk mempelajari skenario dalam waktu beberapa hari sebelum Kegiatan Belajar Mengajar.

c. Guru membentuk kelompok yang anggotanya lima orang (menyesuaikan jumlah siswa).

d. Memberikan penjelasan tentang kompetensi yang ingin dicapai.

e. Memanggil para siswa yang sudah ditunjuk untuk melakonkan skenario yang sudah dipersiapkan.

f. Masing-masing siswa berada di kelompoknya sambil mengamati skenario yang sedang diperagakan.

g. Setelah selesai ditampilkan, masing-masing siswa diberi lembar kerja untuk membahas penampilan yang selesai diperagakan.

h. Masing-masing kelompok menyampaikan hasil kesimpulannya.

i. Guru memberi kesimpulan secara umum.

j. Evaluasi

k. Penutup

Kelebihan model ini adalah, sebagai berikut:

a. Menarik perhatian siswa karena masalahmasalah sosial berguna bagi mereka.

b. Siswa berperan seperti orang lain, sehingga ia dapat merasakan perasaan orang lain, mengakui pendapat orang lain itu, saling pengertian, tenggang rasa, toleransi.

c. Melatih siswa untuk mendesain penemuan.

d. Berpikir dan bertindak kreatif.

e. Memecahkan masalah yang dihadapi secara realistis karena siswa dapat menghayatinya.

f. Mengidentifikasi dan melakukan penyelidikan.

g. Merangsang perkembangan kemajuan berpikir siswa untuk menyelesaikan masalah yang dihadapi dengan tepat. h. Dapat membuat pendidikan sekolah lebih relevan dengan kehidupan, khususnya dunia kerja (Djumingin, 2011: 175-176)

i. Siswa bebas mengambil keputusan dan berekspresi secara utuh

j. Dapat berkesan dengan kuat dan tahan lama dalam ingatan siswa.

k. Sangat menarik bagi siswa, sehingga memungkinkan kelas menjadi dinamis dan penuh antusias.

1. Membangkitkan gairah dan semangat optimisme dalam diri siswa serta menumbuhkan rasa kebersamaan dan kesetiakawanan sosial yang tinggi (Santoso, 2011).

Berikut kelemahan-kelemahan penggunaan Role Playing :

a. Model bermain peranan memerlukan waktu yang relatif panjang/banyak.

b. Memerlukan kreativitas dan daya kreasi yang tinggi dari pihak guru maupun siswa. Dan ini tidak semua guru memilikinya.

c. Tidak semua materi pelajaran dapat disajikan melalui metode ini (Djumingin, 2011: 175-176).

d. Kebanyakan siswa yang ditunjuk sebagai pemeran merasa malu untuk memerlukan suatu adegan tertentu.

Apabila pelaksanaan bermain peran mengalami kegagalan, bukan saja dapat memberi kesan kurang baik, tetapi sekaligus berarti tujuan pengajaran tidak tercapai (Santoso, 2011).

Berdasarkan hasil observasi awal dengan gur PKn Kelas XI MA Sabilal Akhyar Kwala Begumit pada tanggal 10 Mei 2020, saat proses pembelajaran berlangsung karakter siswa sudah cukup baik, namun ada sebagian siswa yang kurang berkarakter. Terlihat dari sikap mereka saat berkomunikasi dengan guru yang menggambarkan sikap kurang sopan dan terlihat juga kurangnya rasa saling menghargai sesama teman. Selain itu, rendahnya moral siswa dan guru kurang menerapkan model- 
model pembelajaran. Penggunaan model pembelajaran yang tepat dan efektif merupakan salah satu faktor yang perlu diperhatikan dalam meningkatkan karakter siswa. Model yang digunakan guru dalam mengajar sangat menentukan keberhasilan siswa dalam membentuk karakter tertentu.

Berdasarkan uraian di atas, maka peneliti mengajukan rumusan masalah yaitu : apakah ada pengaruh peran guru PKn menggunakan model pembelajaran role playing untuk membentuk karakter siswa kelas XI di Madrasah Aliyah Sabilal Akhyar Kwala Begumit?

Adapun tujuan dalam penelitian ini adalah untuk membentuk karakter siswa dengan model pembelajaran Role Playing Kelas XI di MA Sabilal Akhyar, sehingga hasil penelitian ini diharapkan bermanfaat untuk meningkatkan dan membentuk karakter siswa. Hasil penelitian ini juga dapat dijadikan rujukan bagi upaya guru dalam membentuk karakter siswa. Hasil penelitian ini juga dapat digunakan sebagai bahan rujukan bagi penelitian-penelitian berikutnya yang mempunyai relevansi dengan masalah penelitian ini. Hasil penelitian ini diharapkan dapat bermanfaat dan menjadi bahan pustaka bagi sekolah dalam kaitannya mengenai peran guru PKn untuk membentuk karakter siswa.

\section{METOdOLOGI PENELITIAN}

Penelitian ini dilaksanakan di Kelas XI Madrasah Aliyah Sabilal Akhyar yang berlokasi di Kwala Begumit, Kabupaten Langkat. Penelitian ini dilakukan di kelas XI. Penelitian ini dilakukan pada semester ganjil. Populasi adalah keseluruhan subyek penelitian. Sedangkan sampel adalah sebagian yang diambil dari populasi dengan menggunakan metode tertentu. Sampel juga dapat diartikan bagian dari populasi yang menjadi objek penelitian (Syahrum dan Salim, 2012:113). Adapun yang menjadi populasi dalam penelitian ini adalah seluruh siswa kelas XI MA Sabilal Akhyar Kwala Begumit. dengan jumlah 62 siswa, seperti yang ditunjukkan pada tabel berikut.

Tabel 1. Populasi Penelitian

\begin{tabular}{cccc} 
No & Kelompok & Kelas & Jumlah Siswa \\
\hline 1 & Kontrol & XI A & 32 \\
\hline 2 & Eksperimen & XI B & 30 \\
\hline & Jumlah & & 62 \\
\hline
\end{tabular}

Sumber: TU MA Sabilal Akhyar Kwala Begumit

Dalam menentukan sampel, peneliti berpedoman kepada pendapat Arikunto (2006:102) bahwa untuk sekedar ancar-ancar maka apabila subjeknya kurang dari 100, lebih baik diambil semua sehingga penelitiannya merupakan penelitian populasi. Selanjutnya apabila jumlah subjeknya besar maka dapat diambil antara $10-15 \%$ atau $20-25 \%$ atau lebih. Sampel yang diambil dalam penelitian ini adalah siswa kelas XI-A dengan jumlah siswa 32 siswa sebagai kelas kontrol dan siswa kelas
XI-B dengan jumlah 30 siswa sebagai kelas eksperimen dengan pertimbangan bahwa kelas tersebut mempunyai kemampuan yang sama.

Jenis/ Metode penelitian yang digunakan penulis adalah metode eksperimen semu (Quasi Eksperimen). Metode penelitian merupakan cara pemecahan masalah penelitian yang dilaksanakan secara terencana dan cermat dengan maksud mendapatkan fakta dan kesimpulan agar dapat memahami, menjelaskan, meramalkan dan mengendalikan 
keadaan (Syamsuddin dan Damayanti, 2011:14).

Untuk mempermudah dalam pengumpulan data dan analisis data, maka dalam penelitian ini penulis menggunakan instrumen penelitian berupa tes dan angket. Desain penelitian ini menggunakan metode eksperimen semu. Pendekatan kuantitatif digunakan agar semua gejala yang diobservasi dapat diukur dan diubah dalam bentuk angkaangka sehingga memungkinkan digunakan analisis statistik.

Untuk memperoleh data yang diperlukan dalam penelitian ini penulis menggunakan teknik tes. Tes yang digunakan dalam penelitian ini terdiri dari tes tahap awal (pretest) dan tes tahap akhir (posttest).

Dengan cara demikian maka akan dapat diketahui apakah hasil tes akhir lebih baik sama, ataukah lebih jelek dari tesawal. Jika hasil tes itu lebih baik daripada tes awal, maka dapat diartikan bahwa program pengajaran telah berjalan dan berhasil dengan sebaikbaiknya (Sudijono, 2013: 70).

Setelah semua data terkumpul selanjutnya dilakukan analisis data, yaitu pengujian normalitas untuk mengetahui normal tidaknya suatu distribusi data. Hal ini penting diketahui berkaitan dengan ketetapan pemilihan uji statistik yang akan digunakan. Setelah data penelitian ini memenui syarat uji normalitas maka data tersebut akan dianalisis dengan langkah-langkah sebagai berikut:

1. Menentukan Mean, dengan menggunakan rumus (Arikunto 2006:128)

$$
\bar{x}=\frac{\sum X_{1}}{n}
$$

Dimana:

$\mathrm{X}=$ Mean (Rata-rata)

$\sum X_{1} \quad=$ Jumlah Nilai Tes

$\mathrm{N}=$ Jumlah Sampel

2 Standar Deviasi (s), Dengan menggunakan rumus ( Arikunto 2006:129)

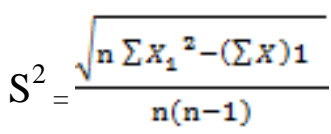

Dimana

$\mathrm{S}^{2}=$ Standar Deviasi

$\sum \mathrm{X}_{1}{ }^{2} \quad=$ Rata-Rata Nilai Tes

$\mathrm{N}=$ Jumlah Sampel

Untuk mengetahui apakah terdapat pengaruh antar variabel (X) dengan variabel terikat (Y) dalam membuktikan benar atau tidaknya hipotesa yang diajukan, maka digunakan rumus uji t. uji t yang digunakan untuk varians antara kedua kelompok jika dikatakanhomogen yaitu sebagai berikut (Arikunto 2006: 246-247)

$$
\begin{aligned}
& \mathrm{t}=\frac{x_{1}-x_{z}}{\operatorname{sd} \sqrt{\frac{z}{n_{1}}}+\frac{1}{n_{2}}} \\
& (\mathrm{SD})^{2}=\frac{(\mathrm{N}-1)\left(\mathrm{SD}_{1}\right)^{2+}\left(\mathrm{N}_{2}-1\right)(\mathrm{SD})_{2}{ }^{2}}{\mathrm{n}-1}
\end{aligned}
$$

Dimana:

$$
\begin{array}{ll}
\mathrm{SD}^{2} & =\text { Varians } \\
\mathrm{SD}_{1} & =\text { Standar Deviasi Pre Tes } \\
\mathrm{SD}_{2} & =\text { Standar Deviasi Post Tes } \\
\mathrm{n} & =\text { Jumlah Sampel }
\end{array}
$$

Selanjutnya untuk menguji hipotesis apakah kebenarannya diterima atau tidak digunakan uji $\mathrm{t}$ student dengan rumus sebagai berikut:

$\mathrm{t}=\left(\mathrm{M}_{1}-\mathrm{M}_{2}\right) / \mathrm{SD} \mathrm{M}_{1}-\mathrm{SDM}_{2}$

Keterangan:

$\mathrm{T}=$ Harga $\mathrm{t}$ hitung

$\mathrm{M}_{1} \quad=$ Nilai rata-rata pre tes

$\mathrm{M}_{2} \quad=$ Nilai rata-rata pre tes

$(\mathrm{SD})^{2}=$ Varians masing-masing nilai tes

Selanjutnya, mengkonsultasikan harga t-tabel pada taraf signifikan $5 \%$ dengan kriteria sebagai jika $t_{\text {hitung }} \geq t_{\text {tabel }}$ maka signifikasi (hipotesis diterima) dan jika $t_{\text {hitung }} \leq t_{\text {tabel }}$ maka signifikasi (hipotesis ditolak)

\section{HASIL DAN PEMBAHASAN}

Sebelum kedua kelas diberikan perlakuan pembelajaran yang berbeda terlebih dahulu diberikan pretest pemahaman materi PKn 


\section{Jurnal Serunai Pancasila dan Kewarganegaraan \\ Vol 9, No. 2, Oktober 2020 \\ e-ISSN 2655-8386}

dengan membentuk karakter siswa. Hasil pretest pemahaman materi pendidikan kewarganegaraan dengan membentuk karakter siswa kedua kelas, yaitu kelas eksperimen dan kelas kontrol yang telah diperoleh dapat disajikan dalam tabel dibawah ini.

Tabel 2. Hasil Pretest Kelas Eksperimen dan Kelas Kontrol

\begin{tabular}{cccccc} 
Kelas & N & Minimum & Maximum & Mean & Std. Deviation \\
\hline Pretest Eksperimen & 30 & 10 & 100 & 43,66 & 23,71 \\
\hline Pretest Kontrol & 32 & 10 & 100 & 45,93 & 25,25
\end{tabular}

Sumber: Diolah dari data primer.

Berdasarkan tabel di atas diketahui jumlah frekuensi siswa kelas eksperimen sebanyak 30 siswa dengan nilai terendah 10 dan nilai teritnggi 100 , serta nilai rata-rata sebesar 43,66 dan standar deviasinya 23,71. Jumlah frekuensi siswa kelas kontrol sebanyak 32 siswa dengan nilai terendah 10 dan nilai teritnggi 100, serta nilai rata-rata sebesar 45,93 dan standar deviasinya 25,25. Diketahu bahwa hasil pretest pemahaman materi pendidikan kewarganegaraan dengan membentuk karakter siswa pada nilai rata-rata kelas eksperimen dan kelas kontrol tidak terdapat perbedaan yang signifikan atau dengan kata lain rata-rata pretest kelas eksperimen dan kelas kontrol tidak jauh berbeda.

Setelah kedua kelas diberikan perlakuan menggunakan model pembelajaran yang berbeda, selanjutnya diberikan potttest pemahaman materi pendidikan kewarganegaraan dengan membentuk karakter siswa. Hasil posttest pemahaman materi pendidikan kewarganegaraan dengan membentuk karakter siswa kedua kelas, yaitu kelas eksperimen dan kelas kontrol yang telah diperoleh dapat disajikan dalam tabel dibawah ini.

Tabel 3. Hasil Posttest Kelas Eksperimen dan Kelas Kontrol

\begin{tabular}{cccccc} 
Kelas & N & Minimum & Maximum & Mean & Std. Deviation \\
\hline Posttest Eksperimen & 30 & 20.00 & 100 & 73,33 & 21,38 \\
\hline Posttest Kontrol & 32 & 10.00 & 100 & 46,56 & 25,09 \\
\hline
\end{tabular}

Sumber: Diolah dari data primer.

Berdasarkan tabel diatas diketahui jumlah frekuensi siswa kelas eksperimen sebanyak 30 siswa dengan nilai terendah 20 dan nilai teritnggi 100 , serta nilai rata-rata sebesar 73,33 dan standar deviasinya 21,38. Jumlah frekuensi siswa kelas kontrol sebanyak 32 siswa dengan nilai terendah 10 dan nilai teritnggi 100, serta nilai rata-rata sebesar 46,56 dan standar deviasinya 25,09. Diketahu bahwa hasil posttest pemahaman materi pendidikan kewarganegaraan dengan membentuk karakter siswa pada nilai rata-rata kelas eksperimen dan kelas kontrol terdapat perbedaan yang signifikan atau dengan kata lain rata-rata 
posttest kelas eksperimen dan kelas kontrol jauh berbeda.

Data pendapat atau sikap siswa terhadap penggunaan model pembelajaran Role Playing diperoleh dari angket yang terdiri atas 10 butir pertanyaan dan pernyataan. Skor maksimal yang mungkin diperoleh siswa adalah100 dan skor minimalnya adalah 0 . Kemudian untuk menentukan kriteria/ kategori pendapat atau sikap siswa terhadap penggunaan model pembelajaran Role Playing adalah dengan mengkonsultasikan skor yang diperoleh siswa pada tabel kritria interpretasi skor di bawah ini.

Tabel 4. Kriteria Interpretasi Skor

\begin{tabular}{ccc} 
No & Rentang Skor & Kategori \\
\hline 1 & $0 \%-20 \%$ & Sangat Rendah \\
\hline 2 & $21 \%-40 \%$ & Rendah \\
\hline 3 & $41 \%-60 \%$ & Cukup \\
\hline 4 & $61 \%-80 \%$ & Tinggi \\
\hline 5 & $81-100 \%$ & Sangat Tinggi
\end{tabular}

Sumber: Riduwan, 2010:89

Data hasil penelitian mengenai pendapat atau sikap siswa terhadap penggunaan model

pembelajaran Role Playing, dapat disajikan pada tabel dan berikut ini.

Tabel 5. Kriteria Interpretasi Skor Angket

\begin{tabular}{ccccc} 
No & Rentang Skor & Kategori & $\begin{array}{c}\text { Jumlah } \\
\text { Siswa }\end{array}$ & Persentase \\
\hline 1 & $0 \%-20 \%$ & Sangat Rendah & 1 & $\frac{1}{30} \times 100 \%=3,33 \%$ \\
\hline 2 & $21 \%-40 \%$ & Rendah & 2 & $\frac{2}{30} \times 100 \%=6,66 \%$ \\
\hline 3 & $41 \%-60 \%$ & Cukup & 6 & $\frac{6}{30} \times 100 \%=20 \%$ \\
\hline 4 & $61 \%-80 \%$ & Tinggi & 15 & $\frac{15}{30} \times 100 \%=50 \%$ \\
\hline 5 & $81-100 \%$ & Sangat Tinggi & 6 & $\frac{6}{30} \times 100 \%=50 \%$ \\
\hline Jumlah & & 30 & $100 \%$
\end{tabular}

Sumber: Diolah dari data primer

Berdasarkan tabel di atas, diketahui bahwa jumlah siswa yang memiliki pendapat atau sikap siswa terhadap penggunaan model pembelajaran Role Playing dengan katergori sangat rendah sebanyak 1 orang $(3,33 \%)$, jumlah siswa yang memiliki pendapat atau sikap siswa terhadap penggunaan model pembelajaran Role Playing dengan katergori rendah sebanyak 2 orang $(6,66 \%)$, jumlah siswa yang memiliki pendapat atau sikap siswa 
terhadap penggunaan model pembelajaran Role Playing dengan katergori cukup sebanyak 6 orang (20\%), jumlah siswa yang memiliki pendapat atau sikap siswa terhadap penggunaan model pembelajaran Role Playing dengan katergori tinggi sebanyak 15 orang (50\%), dan jumlah siswa yang memiliki pendapat atau sikap siswa terhadap penggunaan model pembelajaran Role Playing dengan katergori sangat tinggi sebanyak 6 orang $(6,66 \%)$. Berdasarkan data hasil penelitian dapat disimpulkan bahwa pendapat atau sikap siswa terhadap penggunaan model pembelajaran Role Playing termasuk dalam kategori tinggi. Artinya penerapan pembelajaran Role Playing yang dilakukan guru dapat mempengaruhi antusias siswa dalam materi pendidikan kewarganegaraan dengan membentuk karakter siswa.

Salah satu persyaratan analisis yang harus dipenuhi agar dapat menggunakan statistik parametrik adalah sebaran data dari setiap variabel harus berdistribusi normal. Pengujian normalitas data penelitian di uji dengan menggunakan uji kolmogorov smirnov dengan SPSS 16. Syarat normal yang harus dipenuhi adalah nilai signifikansi $>0,05$ pada taraf signifikan $\alpha=0,05$. Hasil perhitungan uji normalitas data pretest pemahaman materi pendidikan kewarganegaraan dengan membentuk karakter siswa kedua kelas dapat dilihat dalam tabel berikut.

Tabel 6. Hasil Uji Normalitas Data Pretest Kelas Eksperimen dan Kelas Kontrol

\begin{tabular}{cccc} 
Data & Kelas & Nilai Signifikansi & Keterangan \\
\hline \multirow{2}{*}{ Pretest } & Eksperimen & 0,708 & Normal \\
\cline { 2 - 4 } & Kontrol & 0,707 & Normal \\
\hline
\end{tabular}

Sumber: Diolah dari data primer

Tabel di atas menunjukkan hasil perhitungan uji normalitas pretest pemahaman materi pendidikan kewarganegaraan dengan membentuk karakter siswa kelas eksperimen dan kelas kontrol berdistribusi normal. Berdasarkan perhitungan diperoleh nilai signifikansi >0,05. Dengan demikian data pretest pemahaman materi pendidikan kewarganegaraan dengan membentuk karakter siswa kelas eksperimen dan kelas kontrol berdistribusi normal. Adapun hasil perhitungan uji normalitas data posttest pemahaman materi pendidikan kewarganegaraan dengan membentuk karakter siswa kedua kelas dapat dilihat dalam tabel berikut.

Tabel 7. Hasil Uji Normalitas Posttest Kelas Eksperimen dan Kelas Kontrol

\begin{tabular}{cccc} 
Data & Kelas & Nilai Signifikansi & Keterangan \\
\hline \multirow{2}{*}{ Posttest } & Eksperimen & 0,617 & Normal \\
\cline { 2 - 4 } & Kontrol & 0,610 & Normal \\
\hline
\end{tabular}

Sumber: Diolah dari data primer.

Tabel di atas menunjukkan hasil perhitungan uji normalitas posttest pemahaman materi pendidikan kewarganegaraan dengan membentuk karakter siswa kelas eksperimen dan kelas kontrol berdistribusi normal. Berdasarkan perhitungan diperoleh nilai signifikansi $>0,05$. Dengan demikian data pretest pemahaman materi pendidikan 
kewarganegaraan dengan membentuk karakter siswa kelas eksperimen dan kelas kontrol berdistribusi normal. Selanjunta adalah pengujian homogenitas data dilakukan dengan uji levene test pada SPSS 16. Data untuk setiap variabel penelitian dikatakan homogen apabila nilai signifikansi $>0,05$ pada taraf signifikansi $\alpha=5 \%$ dan dk pembilang 29; dk penyebut 31 . Hasil perhitungan uji homogenitas data pretest pemahaman materi pendidikan kewarganegaraan dengan membentuk karakter siswa kedua kelas dapat dilihat dalam tabel berikut.

Tabel 8. Hasil Uji Homogenitas Pretest Kelas Eksperimen dan Kelas Kontrol

\begin{tabular}{cccc} 
Data & Kelas & Nilai Signifikansi & Kesimpulan \\
\hline \multirow{2}{*}{ Pretest } & Eksperimen & 0,603 & \multirow{2}{*}{ Homogen }
\end{tabular}

Sumber: Diolah dari data primer.

Tabel di atas menunjukkan hasil perhitungan uji homogenitas pretest pemahaman materi pendidikan kewarganegaraan dengan membentuk karakter siswa kelas eksperimen dan kelas kontrol adalah homogen. Berdasarkan perhitungan dengan menggunakan uji levene test pada SPSS 16 diperoleh nilai signifikansi $>0,05$ pada taraf signifikansi $\alpha=5 \%$.

Berdasarkan hal tersebut maka populasi kedua kelas berdasarkan data pretest yang telah diuji homogenitasnya adalah homogen. Adapun hasil perhitingan uji homogenitas data postest pemahaman materi pendidikan kewarganegaraan dengan membentuk karakter siswa kedua kelas (eksperimen dan kontrol) dapat dilihat pada tabel berikut.

Tabel 9. Hasil Uji Homogenitas Posttest Kelas Eksperimen dan Kelas Kontrol

\begin{tabular}{cccc} 
Data & Kelas & $\begin{array}{c}\text { Nilai } \\
\text { Signifikansi }\end{array}$ & Kesimpulan \\
\cline { 1 - 2 } Posttest & Eksperimen & 0,258 & Homogen \\
& Kontrol & &
\end{tabular}

Sumber: Diolah dari data primer.

Tabel 10. Hasil Uji Hipotesis

\begin{tabular}{cccc} 
Kelas & $\mathrm{t}_{\text {hitung }}$ & $\mathrm{t}_{\text {tabel }}$ & Kesimpulan \\
\cline { 1 - 2 } & 4,5 & 2,05 & Terima $\mathrm{H}_{\mathrm{a}}$
\end{tabular}

Sumber: Diolah dari data primer.
Tabel di atas menunjukkan hasil perhitungan uji homogenitas postest pemahaman materi pendidikan kewarganegaraan dengan membentuk karakter siswa kelas eksperimen dan kelas kontrol adalah homogen. Berdasarkan perhitungan dengan menggunakan uji levene test pada SPSS 16 diperoleh nilai signifikansi $>0,05$ pada taraf signifikansi $\alpha=5 \%$. Dengan demikian populasi kedua kelas berdasarkan data postest yang telah diuji homogenitasnya adalah homogen.

Pengujian hipotesis dalam penelitian ini menggunakan teknik uji $\mathrm{t}$ dengan dua sampel. Kriteria pengujian adalah terima $\mathrm{H}_{0}$ jika $\mathrm{t}_{\text {hitung }}<$ $t_{\text {tabel }}$ dan terima $H_{a}$ jika $t_{\text {hitung }} \geq t_{\text {tabel }}$. Hasil perhitungan uji hipotesis dalam penelitian ini dapat dilihat dalam tabel berikut. 
Tabel di atas menunjukkan hasil perhitungan uji hipotesis pemahaman materi pendidikan kewarganegaraan dengan membentuk karakter siswa kedua kelas. Berdasarkan perhitungan dengan menggunakan uji t dua sampel diperoleh hasil $t_{\text {hitung }}$ adalah 4,5 sedangkan nilai $t_{\text {tabel }}$ adalah 2,05. Dengan demikian $t_{\text {hitung }}>t_{\text {tabel }}$ ini berarti menerima kriteria pengunjian yaitu terima $\mathrm{H}_{\mathrm{a}}$ yaitu ada pengaruh peran guru PKn membentuk karakter siswa Kelas XI Madrasah Aliyah Sabilal Akhyar dengan menggunakan model Role Playing.

Setelah diberikan pembelajaran dengan model yang berbeda terhadap masing-masing kelas maka selanjutnya diberikan posttest pemahaman materi pendidikan kewarganegaraan dengan membentuk karakter siswa untuk mengetahui perbedaan pemahaman materi pendidikan kewarganegaraan dengan membentuk karakter siswa antara kelas eksperimen yang diajarkan menggunakan model pembelajaran Role Playing, dan kelas kontrol yang diajarkan menggunakan model konvensional.

Dari hasil postest diperoleh nilai rata-rata kelas eksperimen dan kelas kontrol berturutturut sebesar 73,33 dan 46,56. Nilai terendah hasil posttest kelas ekperimen adalah 20 sedangkan nilai terendah kelas kontrol yaitu 10, nilai tertinggi hasil posttest kelas ekperimen adalah 100 dan kelas kontrol adalah 100. Normalitas data posttest kelas ekperimen adalah 0,617 dan kelas kontrol adalah 0,610 dimana keduanya lebih besar dari 0,05 yang berarti data kedua tersebut berdistribusi normal, homogenitas dari data posttes didapat nilai siginifikansi yang lebih besar dari 0,05 yang berarti sampel penelitian ini berasal dari kelas yang homogen, dan uji hipotesis dari data posttest menunjukkan nilai $t_{\text {hitung }}=4,5$ dimana nilai ini lebih besar dari nilai $t_{\text {tabel }}=2,05$ yang berarti terdapat pengaruh peran guru PKn membentuk karakter dengan menggunakan model Role Playing dapat diterima. Hal ini juga memberikan pengertian bahwa pembelajaran dengan menggunakan model pembelajaran Role Playing dapat memberikan hasil pembentukan karakter yang lebih baik dibandingkan dengan pembelajaran yang menggunakan model pembelajaran konvensional.

Tentu saja hal ini berkaitan dengan perlakuan yang diberikan pada kedua kelas yang berbeda. Pada kelas yang diajarkan dengan model pembelajaran Role Playing (bermain peran) ini adalah salah satu bentuk permainan pendidikan yang di gunakan untuk menjelaskan perasaan, sikap, tingkah laku dan nilai, dengan tujuan untuk menghayati perasaan, sudut pandangan dan cara berfikir orang lain. Pengertian bermain peran atau Role Playing adalah metode pembelajaran yang di dalamnya terdapat perilaku pura-pura dari siswa sesuai dengan peran yang telah ditentukan, dimana siswa menirukan situasi dari tokoh sedemikian rupa dengan tujuan mendramatisasikan dan mengekspresikan tingkah laku, ungkapan, gerak-gerik seseorang dalam hubungan sosial antar manusia.

Metode bermain peran dapat memberikan pengalaman belajar, seperti kemampuan untuk bekerjasama, komunikatif, dan menginterpretasikan suatu kejadian. Melalui bermain peran, siswa mencoba mengeksplorasi hubungan antar manusia dengan cara memperagakan dan mendiskusikannya, sehingga secara bersamasama para siswa dapat mengeksplorasi perasaan, sikap, nilai dan strategi pemecahan masalah. Model pembelajaran bermain peran memiliki penekanan yang terletak pada keterlibatan emosional dan pengamatan indera ke dalam suatu situasi masalah yang secara 
nyata dihadapi. Murid diperlakukan sebagai subyek pembelajaran secara aktif melakukan praktik berbahasa (bertanya dan menjawab) pada situasi tertentu.

Model ini dapat memberikan kesan dengan kuat dan tahan lama dalam ingatan siswa, akan menjadi pengalaman yang menyenangkan dan memberi pengetahuan yang melekat dalam memori otak. Model ini sangat menarik bagi siswa sehingga akan membuat kelas menjadi dinamis dan antusias, dapat membangkitkan gairah dan semangat optimisme serta menumbuhkan rasa kebersamaan.

Melalui model ini juga siswa dapat terjun langsung untuk memerankan sesuatu yang akan dibahas dalam proses belajar, sedangkan dalam pembelajaran konvensioanl, guru cenderung menggunakan metode ceramah dengan mengikuti urutan materi dalam kurikulum secara ketat. Guru berasumsi bahwa keberhasilan program pembelajaran dilihat dari ketuntasan menyampaikan seluruh materi yang ada dalam kurikulum. Metode pembelajaran tersebut adalah sering terjadi kesulitan untuk menjaga agar siswa tetap tertarik dengan apa yang dipelajari. Sebab, metode pembelajaran konvensional cenderung membosankan, membuat daya serap rendah, cepat hilang, karena bersifat menghafal. Selain itu, pembelajaran konvensional lebih menekankan kepada penguasaan konsep-konsep, bukan kompetensi. Sebaiknya penerapan model pembelajaran konvensional tidak diterapkan pada kelas yang heterogen.

\section{KESIMPULAN}

Dari hasil penelitian dan analisis data dapat disimpulkan bahwa terdapat pengaruh peran guru PKn membentuk karakter siswa Kelas XI Madrasah Aliyah Sabilal Akhyar dengan menggunakan model pembelajaran Role Playing tahun pelajaran 2020/2021.
DAFTAR PUSTAKA

Anggraini, Retno dan Wibawa, Surya. 2019. "Peran Guru Pendidikan Kewarganegaraan Dalam Penerapan Etika Dan Moral Peserta Didik Dalam Lingkungan Formal Di Smk Negeri 1 Stabat Tahun Pelajaran 2018/2019”. Jurnal Serunai Pancasila dan Kewarganegaraan Vol 8, No. 2.

Arikunto, Suharsimi. 2006. Prosuder Penelitian Suatu Pendekatan Praktek. Jakarta: PT. Rineka Cipta.

Aunillah, Nurla Isna. 2011. Panduan Menerapkan Pendidikan Karakter di Sekolah. Yogyakarta: Laksana.

Djumingin, Sulastriningsih. 2011. Strategi dan Aplikasi Model Pembelajaran Inovatif Bahasa dan Sastra. Makassar: Badan Penerbit UNM.

Hamalik, Oemar, 2012. Manajemen Pengembangan Kurikulum. Bandung: Remaja Rosdakarya.

Hamzah, Uno B. 2007. Model Pembelajaran Menciptakan Proses Belajar Mengajar yang Kreatif dan Efektif. Jakarta: Bumi Aksara.

Huda, Miftahul. 2014. Model-Model Pengajaran dan Pembelajaran. Yogyakarta: Pustaka Pelajar.

Mulyadi. 2011. Paedogogik Khusus Model Pembelajaran Inovatif Di Sekolah Dasar/MI. Surakarta: Badan Penerbit FKIP-UMS.

Salim dan Syahrum, 2012. Metodologi Penelitian, Bandung: Citapustaka Media.

Sudijiono, Anas. 2012. Pengantar Evaluasi Pendidikan. Jakarta: PT Raja Grafindo Persada. 